\title{
GASTRO-INTESTINAL STUDIES. II. PANCREATIC ENZYMES IN PERNICIOUS ANEMIA
}

\author{
By O. M. HELMER, PAUL J. FOUTS AND L. G. ZERFAS
}

(From the Lilly Laboratory for Clinical Research, Indianapolis City Hospital, and the Department of Medicine, Indiana University School of Medicine, Indianapolis)

(Received for publication December 5, 1932)

In a previous article (1) an attempt was made to correlate the findings in the gastric juice of patients having pernicious anemia with the clinical condition of the patients, the degree of central nervous system involvement present, and the maintenance dose of liver extract. Little or no correlation could be found; therefore, this study of the duodenal contents of patients having pernicious anemia was undertaken. The work of Castle and his associates (2) also indicated that additional studies on the digestion of proteins in cases of pernicious anemia should be carried out.

Ehrmann and Lederer (3) (1908) were the first to describe the results of duodenal analyses in cases of achylia gastrica, normal or slightly higher values being found by them. Einhorn (4) (1910) reported the results of the examination of 7 cases of achylia gastrica, in which 4 had normal trypsin values, 1 a low value, and 2 a complete absence of trypsin. In 1914 he reported (5) two cases of achylia gastrica with chronic pancreatitis in which there was an absence of trypsin but in which the other duodenal enzymes were approximately normal. He found (6) high enzymatic activity in the duodenal contents of 3 other cases with achylia gastrica, in 1918.

Crohn (7), in 1913, recorded a case of gastric achylia in which there were normal amounts of all duodenal enzymes except pancreatic rennin. In 1915, he (8) stated that "in my present series, consisting of over 120 cases, 103 cases are regarded as presenting normal pancreatic function; these include many pathological conditions; gastric lesions, benign and malignant, achylia gastrica, organic syphilis, exophthalmic goitre, secondary and primary anemias, malignant growths of various organs, diabetes mellitus, etc." Chace and Myers (9), in 1913, reported 1 case of pernicious anemia and 3 other cases of achylia gastrica in which there were normal amounts of duodenal enzymes. White (10), in 1916, studied another case of pernicious anemia and 3 other cases of achylia gastrica, all four having normal or high pancreatic enzyme values. In 1922, McClure and Jones (11), after studying two cases of pernicious anemia in severe relapse and two other cases of achylia gastrica, concluded that "in achylia gastrica and pernicious anemia no abnormalities in activity of 
the external secretory function of the pancreas were demonstrable, as measured by the enzyme determination of the duodenal contents." In 1922, Roth and Sternberg (12) reported 6 cases of achylia gastrica in which the pancreatic enzymes were present. Kahn (13) also, in 1923, described one case of sprue with gastric and pancreatic achylia. The pancreatic achylia disappeared on proper diet, although the gastric achylia persisted. McClure, Montague, and Mortimer (14), in 1924, found another case of achylia gastrica in which the pancreas functioned normally both as to enzymes and alkaline fluid. Silverman and Denis (15), in 1924, observed one case of achylia gastrica with approximately normal duodenal enzymes. Piersol and Bockus (16) recorded the findings in 3 cases of achylia gastrica in 1925. In two of these cases there was a rather low trypsin activity, while, in the third, trypsin was absent in one examination and present in a higher percentage than normal in another. Landau et al. (17), in 1926, reported 4 cases of pernicious anemia in which there was both gastric and pancreatic achylia. By 1929 Landau and Glass (18) had collected 9 cases of pernicious anemia with both gastric and pancreatic achylia. (Four of these had been reported in their previous article.) They stated that, since the introduction of duodenal and gastric analyses, they had done daily examinations and these nine cases were the only ones in which both gastric and pancreatic achylia was found.

Martin (19), in 1927, found normal amounts of trypsin and diastase in the duodenal contents of two cases of achylia gastrica. Okada et al. (20), in 1929, after studying the pancreatic enzymes of 7 cases of achylia gastrica stated that "evidence that the pancreatic secretion was disturbed as the consequence of disturbed gastric secretion was not found." Cheney and Niemand (21), in 1932, stated that fasting gastric contents contain approximately the same concentration of pancreatic enzymes as the fasting duodenal contents. They made determinations of trypsin on the fasting gastric contents of 10 cases of pernicious anemia in relapse and in 9 of these there was an absence of trypsin, while, in the other, only a small amount of trypsin was found. In 60 other cases (mainly achylias) normal amounts of trypsin were found in the fasting gastric contents.

In the series of experiments reported in this paper, we have attempted not only to evaluate the enzymatic activity of the pancreas, but to determine, as well, the ability of the duodenum to activate the trypsinogen secreted by the pancreas. To do this we have ascertained the tryptic power of the duodenal contents before and after incubation with enterokinase prepared from the duodenal mucosa of hogs.

\section{MATERIAL AND METHODS}

Five young, healthy adults without evidence of disease and having had previous normal gastric analyses were used as controls. All of the 22 cases of 
pernicious anemia were typical clinically and hematologically and had had previous complete gastric analyses. In Table I the clinical and hematological findings in the 22 cases of pernicious anemia are recorded. The results of the gastric analyses in 16 of the 22 patients have been reported previously (1).

TABLE I

The clinical and hematological status of the 22 cases of pernicious anemia

\begin{tabular}{|c|c|c|c|c|c|}
\hline $\begin{array}{c}\text { Case } \\
\text { number }\end{array}$ & Age & Red blood cells & $\begin{array}{l}\text { Hemoglobin } \\
\text { (Newcomer) }\end{array}$ & $\begin{array}{l}\text { Daily maintenance dose } \\
\text { of liver extract no. 343- } \\
\text { derived from grams liver }\end{array}$ & $\begin{array}{l}\text { Central nerv- } \\
\text { ous system } \\
\text { involvement }\end{array}$ \\
\hline & years & $\begin{array}{l}\text { millions } \\
\text { per c.mm. }\end{array}$ & & & \\
\hline 1 & 78 & 2.90 & 65 & & Moderate \\
\hline 2 & 62 & 4.89 & 78 & Intravenous* & Advanced \\
\hline 3 & 59 & 4.86 & 84 & 300 & Advanced \\
\hline 4 & 58 & 5.19 & 92 & 300 & Advanced \\
\hline 5 & 54 & 4.54 & 84 & Intravenous & Early \\
\hline 6 & 46 & 2.99 & 49 & & Early \\
\hline 7 & 55 & 5.64 & 94 & 300 & Advanced \\
\hline 8 & 71 & 4.14 & 86 & 50 & Early \\
\hline 9 & 49 & 4.93 & 73 & & Advanced $\dagger$ \\
\hline 10 & 58 & 5.10 & 78 & Intravenous & Early \\
\hline 11 & 46 & 4.63 & 69 & Intramuscular & Moderate $\dagger$ \\
\hline 12 & 72 & 5.60 & 86 & Intravenous & Advanced \\
\hline 13 & 64 & 4.68 & 83 & Intramuscular & Advanced $\dagger$ \\
\hline 14 & 66 & 5.31 & 110 & 300 & Advanced \\
\hline 15 & 42 & 5.65 & 101 & 300 & Early \\
\hline 16 & 54 & 5.28 & 83 & Intravenous & None \\
\hline 17 & 48 & 4.73 & 88 & & Early \\
\hline 18 & 58 & 5.08 & 89 & 400 & Moderate \\
\hline 19 & 54 & 1.15 & 25 & & Advanced \\
\hline 20 & 48 & 4.95 & 84 & 400 & Early \\
\hline 21 & 62 & 1.73 & 31 & & Advanced \\
\hline 22 & 58 & 1.16 & 27 & & Advanced \\
\hline
\end{tabular}

* Those patients now receiving intravenous or intramuscular liver extract at weekly intervals had previously been unable to maintain the blood at normal levels while receiving at least the amount of liver extract derived from 300 grams of whole liver daily, by mouth.

$\dagger$ Patients showing recent improvement in neurological conditions.

No food or drink was given to the subjects between the evening meal and the morning of the test. Early in the morning the fasting gastric contents were removed by means of a Rehfuss tube while the subject was in a semirecumbent position. The subject then swallowed the tube to approximately the $75 \mathrm{~cm}$. mark and was turned onto the right side. After the subject had rested in this position for from $\frac{1}{2}$ to $\frac{3}{4}$ of an hour, an attempt was made to localize the position of the tube. To localize the tube the following procedures were followed:

1. Auscultation was performed over the epigastrium during the injection of air into the tube. (As stated by Richards (22), if the tip of the tube was in the stomach, a loud cavernous sound was transmitted to the ear of the examiner, but if it was in the duodenum, a more distant, muffled, high pitched sound was heard.) 
2. Sensation of the subject on the injection of the air was noted. (Many of the patients noticed a distinct difference in sensation when the air was injected into the duodenum. The injected air was felt much deeper and very quickly could be felt passing through the intestines.)

3. The rapid disappearance of the acid injected was observed.

4. Persistence of deep bile color to the fluid on removal was noted.

If the above requirements were fulfilled, it was thought that the tip of the tube was in the duodenum and that the fluoroscope was not absolutely necessary to verify the position of the tube. Fluoroscopic examination probably would have helped in several instances in passing the tube into the duodenum, as, occasionally, it was necessary to wait three hours or longer and to change the position of the subject and the tube many times before the tube dropped into the duodenum. On a few occasions the examination was unsuccessful as the tube would not pass into the duodenum.

After localizing the tube, $30^{\circ} \mathrm{cc}$. of 0.2 per cent hydrochloric acid was injected into the tube. One minute later an attempt was made to remove the acid. If most of the acid had disappeared at that time, continuous suction was applied to the tube after five minutes. Two 30 minute samples of duodenal secretions were collected.

The duodenal or gastric juice was measured in a graduated cylinder and filtered through paper. The color was noted and the $\mathrm{pH}$ was determined colorimetrically. Only the results of those samples which were neutral or alkaline were considered to be of value. Silverman and Denis (15) and Wadsworth and Aaron (23) showed the value of this precaution. Our own experience has also taught us that acid duodenal contents gave much lower enzyme values.

Amylase and lipase were determined by the methods described by McClure, Wetmore, and Reynolds (24). However, in the lipase determination, 1 cc. of duodenal juice was diluted to $5 \mathrm{cc}$. with 0.33 molar phosphate buffer instead of to $50 \mathrm{cc}$. Our lower lipase values may be due to the difference in the stimulus used or in the cottonseed oil emulsion.

To determine the tryptic activity of the duodenal juice, $1 \mathrm{cc}$. of the juice was diluted to $10 \mathrm{cc}$. with distilled water, and $5 \mathrm{cc}$. was used for analyses by the method of Koch and Helmer (25) described below. The total tryptic content (trypsin plus trypsinogen) was determined by adding 1 cc. of a 2 per cent solution of enterokinase to $1 \mathrm{cc}$. of duodenal juice, making the total volume to $10 \mathrm{cc}$. with distilled water, and incubating for 30 minutes at $40^{\circ} \mathrm{C}$. Five cc. of the activated solution was then used for the analysis of its tryptic power. The enterokinase was prepared from duodenal mucous membrane of hogs. The mucous membrane previously had been dehydrated and defatted by means of acetone and ether.

The details of the method for the determination of trypsin are as follows: The casein solution, which was used as a substrate, was prepared by shaking 75 grams of Merck's casein (according to Hammarsten) with $500 \mathrm{cc}$. of distilled water in a 2 liter flask until the casein was in a finely divided state. Then 500 cc. of 0.8 per cent sodium carbonate was added and the mixture shaken until the casein was disolved. If preserved with toluene, the solution will keep several days in the ice box.

For the determination, $80 \mathrm{cc}$. of the casein solution was measured into an Erlenmeyer flask of 125 cc. capacity, and enough 0.4 per cent sodium carbonate was added so that the total volume was $100 \mathrm{cc}$. upon the addition of the substance to be tested. The casein solution was then allowed to come to $40^{\circ} \mathrm{C}$. and the trypsin was added. The mixture was stirred well to insure homogeneity, and $25 \mathrm{cc}$. was pipetted into a small beaker or flask containing $3.6 \mathrm{cc}$. of 
normal acetic acid and about 1 gram of talc. (It is important to stir vigorously while adding the casein to the acid to insure a good precipitation.) The remaining solution was allowed to digest for 4 hours at $40^{\circ} \mathrm{C}$. The $25 \mathrm{cc}$. of the solution above served as a blank. The precipitated casein was removed by filtration through a good quantitative paper and the refractive index was read at $25^{\circ} \mathrm{C}$. by means of a Bausch and Lomb immersion refractometer.

At the end of the digestion period, exactly 4 hours, the flask was removed from the incubator and, again, $25 \mathrm{cc}$. of the solution was pipetted off and the undigested casein precipitated as before. The difference in the refractive index of the blank and the 4 hour filtrate was the index of the amount of digestion. The refractive index changes were recorded in scale readings of the refractometer. Since the filtrate from the casein precipitation was water clear, no difficulty was encountered in securing constant readings with the refractometer.

In order to have a standard with which to compare the tryptic activity, a standard curve was made by determining the change in refractive index caused by quantities of U.S. P. pancreatin, ranging from $1 \mathrm{mgm}$. to $20 \mathrm{mgm}$. per 100 cc. of casein solution. The refractive index changes caused by known concentrations of a 0.4 per cent sodium carbonate solution of U. S. P. pancreatin are shown in Table II, and the data from Table II are plotted in Chart 1.

TABLE II

Change in refractive index readings at $25^{\circ} \mathrm{C}$. produced by known concentrations of U.S.P. pancreatin

\begin{tabular}{|c|c|}
\hline Pancreatin & $\begin{array}{l}\text { Change in } \\
\text { refractive index } \\
\text { scale readings } \\
\text { immersion } \\
\text { refractometer }\end{array}$ \\
\hline $\begin{array}{l}1 \ldots \\
2 \ldots \\
4 \ldots \\
6 \ldots \\
8 \ldots \\
10 \ldots \\
15 \ldots \\
20 \ldots\end{array}$ & $\begin{array}{ll}\ldots & 0.72 \\
\ldots & 1.20 \\
\ldots & 2.10 \\
\ldots & 3.35 \\
\ldots & 4.18 \\
\ldots & 5.36 \\
\ldots & 7.45 \\
\ldots & 9.17\end{array}$ \\
\hline
\end{tabular}

To rule out the possibility of pepsin interfering with the trypsin determination, 5 cc. of normal gastric juice with a high pepsin content was allowed to act on casein in the manner outlined above. The gastric juice had no proteolytic activity under these conditions.

\section{RESULTS IN NORMAL SUBJECTS}

In Table III are tabulated the results in normal subjects. The fasting gastric contents all contained a trace of trypsin and lipase. In the samples with acid reaction the amylase was entirely absent. The one specimen which was alkaline had considerable amylolytic power, due, no doubt, to the presence of saliva. This sample also had the greatest tryptic activity.

In the duodenal specimens in which the reaction was neutral or alkaline, the results were quite uniform. Again it was noted that the acid reaction completely inactivated the amylolytic enzyme and markedly de- 


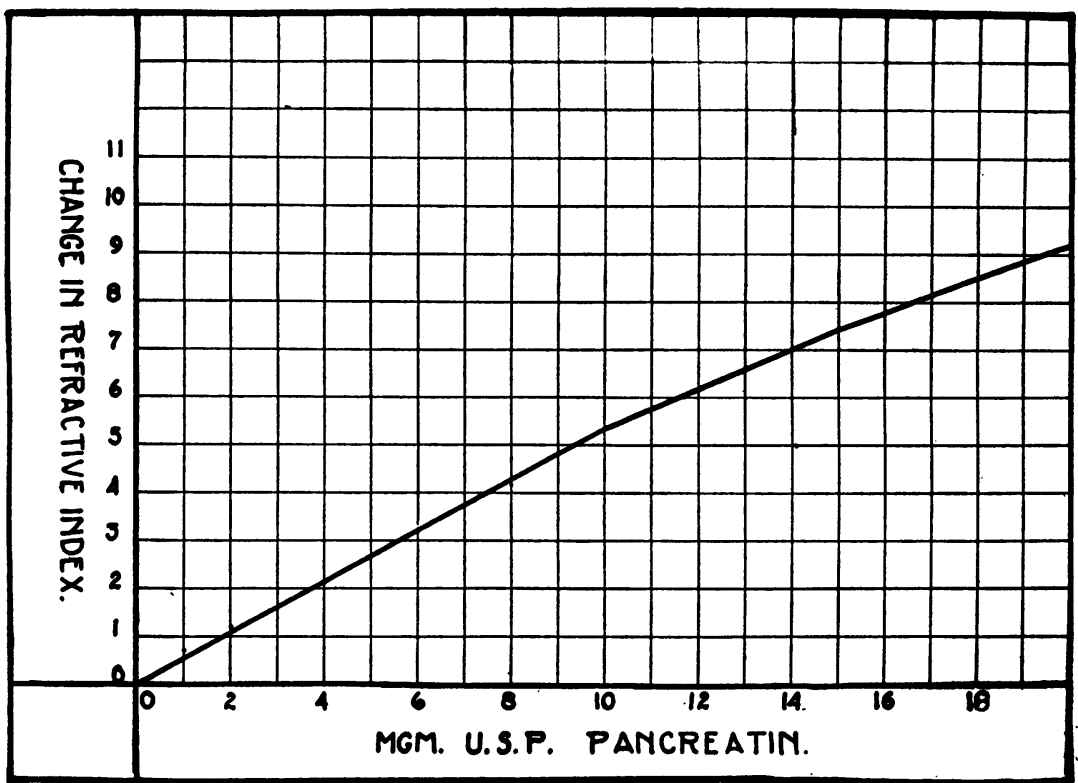

Chart 1. Change in Refractive Index Readings at $25^{\circ} \mathrm{C}$. Produced by Known Concentrations of U. S. P. Pancreatin

TABLE III

The volume, color, $p H$, trypsin before and after activation with enterokinase, lipase, and amylase in the fasting gastric juice and in the duodenal contents following acid stimulation in normal individuals

\begin{tabular}{|c|c|c|c|c|c|c|c|c|c|}
\hline $\begin{array}{c}\text { Case } \\
\text { num- } \\
\text { ber }\end{array}$ & Date & Specimen & $\begin{array}{l}\text { Vol- } \\
\text { ume }\end{array}$ & Color & $\mathrm{pH}$ & $\underset{\sin }{\text { Tryp- }}$ & $\begin{array}{l}\text { Tryp- } \\
\text { sin } \\
\text { and } \\
\text { tryp- } \\
\text { sin- } \\
\text { ogen }\end{array}$ & $\begin{array}{l}\text { Lip- } \\
\text { ase }\end{array}$ & $\begin{array}{c}\text { Amyl- } \\
\text { ase }\end{array}$ \\
\hline \multirow{4}{*}{1} & 1992 & & $c c$. & & & $\begin{array}{c}\text { mgm. } \\
\text { per } \\
c c .\end{array}$ & $\begin{array}{c}\text { mgm. } \\
\text { per } \\
c c .\end{array}$ & $\begin{array}{c}c c . \\
N / 10 \\
N a O H\end{array}$ & $\begin{array}{c}\text { mgm. } \\
\text { glu- } \\
\text { cose }\end{array}$ \\
\hline & \multirow[t]{3}{*}{ September 6} & Fasting gastric & 28 & Negative & 1.8 & 0.3 & 1.8 & 0.0 & 0.0 \\
\hline & & 1st half hour & 80 & Yellow & 7.4 & 13.3 & 27.5 & 3.2 & 2.1 \\
\hline & & $2 \mathrm{~d}$ half hour & 30 & Yellow & 7.4 & 17.0 & 32.9 & 3.5 & 2.9 \\
\hline \multirow[t]{3}{*}{2} & \multirow[t]{3}{*}{ September 8} & Fasting gastric & 23 & Bile & 7.6 & 2.0 & 3.9 & 0.2 & 1.3 \\
\hline & & 1st half hour & 95 & Yellow & 7.8 & 14.2 & 27.7 & 2.7 & 1.0 \\
\hline & & $2 \mathrm{~d}$ half hour & 12 & Yellow & 7.8 & 23.8 & 42.7 & 4.2 & 2.6 \\
\hline \multirow[t]{3}{*}{3} & \multirow[t]{3}{*}{ September 22} & Fasting gastric & 35 & Bile & 1.3 & 1.0 & 1.0 & 0.2 & 0.0 \\
\hline & & 1st half hour & 64 & Yellow & 7.6 & 16.3 & 20.6 & 2.6 & 1.6 \\
\hline & & $2 \mathrm{~d}$ half hour & 46 & Yellow & 4.7 & 6.5 & 13.0 & 1.6 & 0.0 \\
\hline \multirow[t]{3}{*}{4} & \multirow[t]{3}{*}{ October 6} & Fasting gastric & 17 & Negative & 2.2 & 1.8 & 2.2 & 0.2 & 0.0 \\
\hline & & 1st half hour & 110 & Amber & 8.0 & 13.2 & 25.2 & 2.8 & 0.9 \\
\hline & & $2 d$ half hour & 65 & Amber & 8.3 & 15.9 & 31.0 & 4.3 & 1.5 \\
\hline \multirow[t]{2}{*}{5} & \multirow[t]{2}{*}{ October 11} & Fasting gastric & 70 & Bile & 2.0 & 1.0 & 1.2 & 0.1 & 0.9 \\
\hline & & $2 d$ half hour & 107 & Yellow & 7.0 & 12.2 & 22.0 & 2.8 & 0.9 \\
\hline
\end{tabular}


creased the lipolytic and tryptic activity. It was interesting to observe the relatively large amount of trypsinogen that was present in the normal duodenal contents. After activation, the tryptic power of the juice was increased 83 per cent. We believe that the determination of the tryptic power after activation with enterokinase may offer a more accurate index of pancreatic function, since at least two factors must be considered as playing a role in determining the amount of tryptic activity in the duodenal juice-namely, the ability of the pancreas to secrete trypsinogen and the ability of duodenal mucosa to supply enterokinase to activate it.

\section{RESULTS IN PERNICIOUS ANEMIA}

In Table IV the results of the analyses of the gastric and duodenal contents in the 22 cases of pernicious anemia are recorded. The fasting gastric samples contained only small amounts of trypsin and lipase, except in the samples containing bile where there was a noticeable increase in the amount of these enzymes in most cases. Many of the fasting gastric samples contained a greater amount of amylase than the duodenal samples. This was undoubtedly due to the presence of saliva in the fasting gastric contents, since patients with pernicious anemia have no acid in the fasting gastric contents to destroy the amylase of the saliva.

There was an increase in tryptic and lipolytic activity over the fasting gastric findings in all of the duodenal samples. The average of the tryptic activity in the half hour duodenal samples of the 22 cases of pernicious anemia, before activation with enterokinase, was $15.2 \mathrm{mgm}$. per cc. and $21.5 \mathrm{mgm}$. per cc. following the activation. The value obtained before activation was approximately the same as that found in normal persons, but the value after activation was distinctly lower. There was an increase of only 49 per cent of the tryptic value after activation with the enterokinase, as compared with the increase of 83 per cent found in the normal specimens. Therefore, it appears that there is a decreased secretion of trypsinogen in these patients; although their values for tryptic activity by the usual tests fall within the normal range. It is evident from these observations that there is a normal amount of enterokinase secreted by the duodenum. The average of the lipolytic activity in the half hour samples of the cases of pernicious anemia was slightly lower than the normal values. The average amylolytic values were approximately equal to those found in the normal persons.

The 22 cases of pernicious anemia were grouped in Table $\mathrm{V}$ and in Chart 2 according to their clinical and hematological status at the time of the analyses. Those patients having moderate to advanced central nervous system involvement usually had a much lower tryptic activity in the duodenal contents, not only when the tryptic values were compared with the normal findings, but even when these values were compared with those obtained in the patients with pernicious anemia having early or no 
TABLE IV

The volume, color, $p H$, trypsin before and after activation with enterokinase, lipase, and amylase in the fasting gastric juice and in the duodenal contents following acid stimulation in 22 cases of pernicious anemia

\begin{tabular}{|c|c|c|c|c|c|c|c|c|c|}
\hline $\begin{array}{l}\text { Case } \\
\text { num- } \\
\text { ber }\end{array}$ & Date & Specimen & $\begin{array}{l}\text { Vol- } \\
\text { ume }\end{array}$ & Color & $\mathrm{pH}$ & $\underset{\sin }{\text { Tryp- }}$ & $\begin{array}{l}\text { Tryp- } \\
\text { sin } \\
\text { and } \\
\text { tryp- } \\
\text { sin- } \\
\text { ogen }\end{array}$ & $\begin{array}{l}\text { Lip- } \\
\text { ase }\end{array}$ & $\begin{array}{c}\text { Amyl- } \\
\text { ase }\end{array}$ \\
\hline & 1932 & & $c c$. & & & $\begin{array}{c}\text { mgm. } \\
\text { per } \\
c c .\end{array}$ & $\begin{array}{l}\text { mgm. } \\
\text { per } \\
c c .\end{array}$ & $\begin{array}{c}\mathrm{cc} \\
\mathrm{N} / \mathrm{io} \\
\mathrm{NaOH}\end{array}$ & $\begin{array}{c}\operatorname{mgm} . \\
\text { glu- } \\
\text { cose }\end{array}$ \\
\hline 1 & July 6 & $\begin{array}{l}\text { Fasting gastric } \\
\text { 1st half hour } \\
\text { 2d half hour }\end{array}$ & $\begin{array}{l}45 \\
17\end{array}$ & $\begin{array}{l}\text { Green } \\
\text { Yellow }\end{array}$ & & 12.4 & 16.4 & 1.0 & $\begin{array}{l}0.9 \\
0.7\end{array}$ \\
\hline 2 & July 11 & $\begin{array}{l}\text { Fasting gastric } \\
\text { 1st half hour } \\
\text { 2d half hour }\end{array}$ & $\begin{array}{r}3 \\
56 \\
13\end{array}$ & Negative & $\begin{array}{l}8.4 \\
6.8 \\
8.4\end{array}$ & $\begin{array}{l}1.9 \\
3.3 \\
8.0\end{array}$ & $\begin{array}{r}1.7 \\
4.6 \\
11.0\end{array}$ & $\begin{array}{l}0.2 \\
0.2 \\
1.1\end{array}$ & $\begin{array}{l}0.8 \\
0.3 \\
0.9\end{array}$ \\
\hline & October 12 & $\begin{array}{l}\text { Fasting gastric } \\
1 \text { st half hour }\end{array}$ & $\begin{array}{l}13 \\
52\end{array}$ & $\begin{array}{l}\text { Bile } \\
\text { Amber }\end{array}$ & $\begin{array}{l}8.2 \\
8.4\end{array}$ & $\begin{array}{l}0.2 \\
8.2\end{array}$ & $\begin{array}{r}1.0 \\
10.8\end{array}$ & $\begin{array}{l}0.0 \\
0.8\end{array}$ & $\begin{array}{l}1.1 \\
0.9\end{array}$ \\
\hline 3 & July 15 & $\begin{array}{l}\text { Fasting gastric } \\
\text { 1st half hour } \\
\text { 2d half hour }\end{array}$ & $\begin{array}{l}40 \\
56 \\
53\end{array}$ & Negative & & $\begin{array}{r}3.7 \\
9.3 \\
16.1\end{array}$ & $\begin{array}{r}4.2 \\
11.5 \\
25.3\end{array}$ & $\begin{array}{l}0.2 \\
0.5 \\
1.2\end{array}$ & $\begin{array}{l}1.7 \\
1.4 \\
1.8\end{array}$ \\
\hline 4 & July 22 & $\begin{array}{l}\text { Fasting gastric } \\
1 \text { st half hour }\end{array}$ & $\begin{array}{l}13 \\
36\end{array}$ & $\begin{array}{l}\text { Negative } \\
\text { Yellow }\end{array}$ & & $\begin{array}{l}0.2 \\
9.9\end{array}$ & $\begin{array}{r}0.2 \\
17.2\end{array}$ & $\begin{array}{l}0.2 \\
2.2\end{array}$ & $\begin{array}{l}0.6 \\
0.7\end{array}$ \\
\hline 5 & July 27 & $\begin{array}{l}\text { Fasting gastric } \\
\text { 1st half hour } \\
\text { 2d half hour }\end{array}$ & $\begin{array}{r}18 \\
150 \\
63\end{array}$ & $\begin{array}{l}\text { Negative } \\
\text { Green } \\
\text { Green }\end{array}$ & & $\begin{array}{r}0.0 \\
20.0 \\
19.5\end{array}$ & $\begin{array}{r}0.3 \\
29.1 \\
34.8\end{array}$ & $\begin{array}{l}0.1 \\
1.0 \\
1.0\end{array}$ & $\begin{array}{l}2.3 \\
0.8 \\
1.5\end{array}$ \\
\hline 6 & August 11 & $\begin{array}{l}\text { Fasting gastric } \\
\text { 1st half hour } \\
\text { 2d half hour }\end{array}$ & $\begin{array}{l}45 \\
79 \\
50\end{array}$ & $\begin{array}{l}\text { Yellow } \\
\text { Yellow }\end{array}$ & & $\begin{array}{r}2.0 \\
17.2\end{array}$ & $\begin{array}{r}2.6 \\
24.6 \\
30.8\end{array}$ & & $\begin{array}{l}0.8 \\
0.8 \\
1.1\end{array}$ \\
\hline 7 & August 30 & $\begin{array}{l}\text { Fasting gastric } \\
\text { 1st half hour } \\
\text { 2d half hour }\end{array}$ & $\begin{array}{r}3 \\
120 \\
58\end{array}$ & $\begin{array}{l}\text { Negative } \\
\text { Yellow } \\
\text { Yellow }\end{array}$ & & $\begin{array}{r}0.5 \\
9.2 \\
12.3\end{array}$ & $\begin{array}{r}0.5 \\
15.2 \\
16.2\end{array}$ & $\begin{array}{l}0.1 \\
0.7 \\
1.2\end{array}$ & $\begin{array}{l}0.9 \\
2.2 \\
2.5\end{array}$ \\
\hline 8 & September 1 & $\begin{array}{l}\text { Fasting gastric } \\
\text { 1st half hour } \\
\text { 2d half hour }\end{array}$ & $\begin{array}{r}24 \\
75 \\
8\end{array}$ & $\begin{array}{l}\text { Negative } \\
\text { Yellow } \\
\text { Yellow }\end{array}$ & $\begin{array}{l}8.7 \\
7.6 \\
7.6\end{array}$ & $\begin{array}{r}0.0 \\
29.7 \\
24.8\end{array}$ & $\begin{array}{r}0.0 \\
35.2 \\
38.2\end{array}$ & $\begin{array}{l}0.0 \\
3.1 \\
3.2\end{array}$ & $\begin{array}{l}1.3 \\
0.9 \\
3.0\end{array}$ \\
\hline 9 & September 7 & $\begin{array}{l}\text { Fasting gastric } \\
\text { 1st half hour } \\
\text { 2d half hour }\end{array}$ & $\begin{array}{l}13 \\
44 \\
50\end{array}$ & $\begin{array}{l}\text { Negative } \\
\text { Brown } \\
\text { Brown }\end{array}$ & $\begin{array}{l}8.4 \\
7.6 \\
7.8\end{array}$ & $\begin{array}{r}0.6 \\
13.5 \\
14.2\end{array}$ & $\begin{array}{r}0.7 \\
20.0 \\
28.3\end{array}$ & $\begin{array}{l}0.0 \\
3.2 \\
4.4\end{array}$ & $\begin{array}{l}0.9 \\
0.8 \\
2.1\end{array}$ \\
\hline 10 & September 9 & $\begin{array}{l}\text { Fasting gastric } \\
\text { 1st half hour } \\
\text { 2d half hour }\end{array}$ & $\begin{array}{l}88 \\
10\end{array}$ & $\begin{array}{l}\text { Amber } \\
\text { Brown }\end{array}$ & $\begin{array}{l}8.0 \\
8.6\end{array}$ & $\begin{array}{l}15.2 \\
16.3\end{array}$ & $\begin{array}{l}26.6 \\
21.2\end{array}$ & $\begin{array}{l}1.7 \\
1.7\end{array}$ & $\begin{array}{l}2.5 \\
3.0\end{array}$ \\
\hline
\end{tabular}


TABLE IV-Continued

\begin{tabular}{|c|c|c|c|c|c|c|c|c|c|}
\hline $\begin{array}{c}\text { Case } \\
\text { num- } \\
\text { ber }\end{array}$ & Date & Specimen & $\begin{array}{l}\text { Vol- } \\
\text { ume }\end{array}$ & Color & $\mathrm{pH}$ & $\underset{\sin }{\operatorname{Tryp}}$ & $\begin{array}{c}\text { Tryp- } \\
\text { sin } \\
\text { and } \\
\text { tryp- } \\
\text { sino- } \\
\text { gen }\end{array}$ & $\begin{array}{l}\text { Lip- } \\
\text { ase }\end{array}$ & $\underset{\text { ase }}{\text { Amyl- }}$ \\
\hline & 1952 & & $c c$. & & & $\begin{array}{c}\text { mgm. } \\
\text { per. } \\
c c .\end{array}$ & $\begin{array}{c}\text { mgm. } \\
\text { per } \\
c c .\end{array}$ & $\begin{array}{c}c c . \\
\mathrm{N} / \mathrm{ioO} \\
\mathrm{NaOH}\end{array}$ & \begin{tabular}{|c}
$\operatorname{mgm}$. \\
glu- \\
cose
\end{tabular} \\
\hline 11 & September 13 & $\begin{array}{l}\text { Fasting gastric } \\
\text { 1st half hour } \\
2 \mathrm{~d} \text { half hour }\end{array}$ & $\begin{array}{r}16 \\
110 \\
45\end{array}$ & $\begin{array}{l}\text { Bile } \\
\text { Amber } \\
\text { Yellow }\end{array}$ & $\begin{array}{l}7.8 \\
7.8 \\
7.8\end{array}$ & $\begin{array}{r}2.7 \\
12.4 \\
12.4\end{array}$ & $\begin{array}{r}5.3 \\
26.2 \\
21.4\end{array}$ & $\begin{array}{l}0.9 \\
4.2 \\
4.7\end{array}$ & $\begin{array}{l}2.9 \\
3.4 \\
4.8\end{array}$ \\
\hline 12 & September 14 & $\begin{array}{l}\text { Fasting gastric } \\
\text { 1st half hour } \\
\text { 2d half hour }\end{array}$ & $\begin{array}{l}10 \\
95 \\
25\end{array}$ & $\begin{array}{l}\text { Negative } \\
\text { Brown } \\
\text { Brown }\end{array}$ & $\begin{array}{l}8.2 \\
7.8 \\
8.2\end{array}$ & $\begin{array}{r}0.2 \\
18.8 \\
16.7\end{array}$ & $\begin{array}{r}1.0 \\
27.2 \\
24.4\end{array}$ & $\begin{array}{l}0.1 \\
3.4 \\
3.0\end{array}$ & $\begin{array}{l}2.2 \\
1.9 \\
2.3\end{array}$ \\
\hline 13 & September 16 & $\begin{array}{l}\text { Fasting gastric } \\
\text { 1st half hour }\end{array}$ & $\begin{array}{r}2 \\
32\end{array}$ & Yellow & 7.8 & $\begin{array}{r}0.0 \\
20.8\end{array}$ & 28.0 & 4.0 & 1.1 \\
\hline 14 & September 19 & $\begin{array}{l}\text { Fasting gastric } \\
\text { 1st half hour } \\
\text { 2d half hour }\end{array}$ & $\begin{array}{l}41 \\
63 \\
50\end{array}$ & $\begin{array}{l}\text { Negative } \\
\text { Brown } \\
\text { Yellow }\end{array}$ & $\begin{array}{l}8.2 \\
8.2 \\
7.8\end{array}$ & $\begin{array}{r}0.4 \\
15.4 \\
10.4\end{array}$ & \begin{tabular}{r|}
0.5 \\
17.4 \\
14.8
\end{tabular} & $\begin{array}{l}0.2 \\
2.4 \\
2.6\end{array}$ & $\begin{array}{l}2.5 \\
2.1 \\
2.3\end{array}$ \\
\hline 15 & September 20 & $\begin{array}{l}\text { Fasting gastric } \\
\text { 1st half hour } \\
\text { 2d half hour }\end{array}$ & $\begin{array}{l}32 \\
30 \\
19\end{array}$ & $\begin{array}{l}\text { Negative } \\
\text { Brown } \\
\text { Yellow }\end{array}$ & $\begin{array}{l}8.6 \\
7.8 \\
8.2\end{array}$ & $\begin{array}{r}0.4 \\
17.2 \\
15.4\end{array}$ & $\begin{array}{r}1.0 \\
26.0 \\
22.5\end{array}$ & $\begin{array}{l}0.0 \\
3.4 \\
3.0\end{array}$ & $\begin{array}{l}2.3 \\
0.8 \\
1.8\end{array}$ \\
\hline 16 & September 21 & $\begin{array}{l}\text { Fasting gastric } \\
\text { 1st half hour } \\
\text { 2d half hour }\end{array}$ & $\begin{array}{l}58 \\
31 \\
21\end{array}$ & $\begin{array}{l}\text { Bile } \\
\text { Yellow } \\
\text { Blood }\end{array}$ & & $\begin{array}{r}2.6 \\
9.5 \\
23.6\end{array}$ & \begin{tabular}{r|}
5.5 \\
18.2 \\
29.2
\end{tabular} & $\begin{array}{l}0.8 \\
2.2 \\
3.2\end{array}$ & $\begin{array}{l}3.1 \\
1.5 \\
3.8\end{array}$ \\
\hline 17 & September 26 & $\begin{array}{l}\text { Fasting gastric } \\
\text { 1st half hour } \\
\text { 2d half hour }\end{array}$ & $\begin{array}{l}14 \\
80 \\
46\end{array}$ & $\begin{array}{l}\text { Bile } \\
\text { Amber } \\
\text { Amber }\end{array}$ & $\begin{array}{l}7.8 \\
7.6 \\
8.2\end{array}$ & $\begin{array}{l}12.8 \\
38.2 \\
20.0\end{array}$ & $\begin{array}{l}12.2 \\
34.8 \\
25.0\end{array}$ & $\begin{array}{l}0.6 \\
3.0 \\
1.7\end{array}$ & $\begin{array}{l}5.2 \\
2.9 \\
3.7\end{array}$ \\
\hline 18 & September 28 & $\begin{array}{l}\text { Fasting gastric } \\
\text { 1st half hour } \\
\text { 2d half hour }\end{array}$ & $\begin{array}{r}5 \\
65 \\
11\end{array}$ & $\begin{array}{l}\text { Bile } \\
\text { Amber } \\
\text { Blood }\end{array}$ & $\begin{array}{l}8.0 \\
7.8 \\
8.2\end{array}$ & $\begin{array}{r}1.5 \\
10.2 \\
8.9\end{array}$ & $\begin{array}{l}16.9 \\
13.2\end{array}$ & $\begin{array}{l}1.0 \\
1.3\end{array}$ & $\begin{array}{l}2.7 \\
2.6\end{array}$ \\
\hline 19 & September 29 & $\begin{array}{l}\text { Fasting gastric } \\
1 \text { st half hour }\end{array}$ & $\begin{array}{r}9 \\
65\end{array}$ & $\begin{array}{l}\text { Negative } \\
\text { Amber }\end{array}$ & \begin{tabular}{|l|}
8.6 \\
8.2
\end{tabular} & $\begin{array}{r}0.6 \\
10.0\end{array}$ & $\begin{array}{r}1.0 \\
15.6\end{array}$ & $\begin{array}{l}0.2 \\
1.2\end{array}$ & $\begin{array}{l}3.4 \\
1.9\end{array}$ \\
\hline 20 & October 3 & $\begin{array}{l}\text { Fasting gastric } \\
\text { 1st half hour } \\
\text { 2d half hour }\end{array}$ & $\begin{array}{r}29 \\
129 \\
46\end{array}$ & $\begin{array}{l}\text { Negative } \\
\text { Amber } \\
\text { Amber }\end{array}$ & $\begin{array}{l}7.8 \\
8.0 \\
8.2\end{array}$ & $\begin{array}{r}2.7 \\
17.4 \\
17.2\end{array}$ & $\begin{array}{r}6.0 \\
26.6 \\
22.0\end{array}$ & $\begin{array}{l}0.3 \\
3.0 \\
2.0\end{array}$ & $\begin{array}{l}2.3 \\
2.3 \\
3.7\end{array}$ \\
\hline 21 & October 5 & $\begin{array}{l}\text { Fasting gastric } \\
\text { 1st half hour } \\
\text { 2d half hour }\end{array}$ & $\begin{array}{r}3 \\
82 \\
50\end{array}$ & $\begin{array}{l}\text { Amber } \\
\text { Amber }\end{array}$ & \begin{tabular}{|}
8.5 \\
8.4
\end{tabular} & $\begin{array}{r}0.4 \\
9.2 \\
12.8\end{array}$ & $\begin{array}{l}12.0 \\
16.0\end{array}$ & $\begin{array}{l}1.2 \\
1.2\end{array}$ & $\begin{array}{l}0.2 \\
0.2\end{array}$ \\
\hline 22 & October 17 & $\begin{array}{l}\text { Fasting gastric } \\
\text { 1st half hour } \\
\text { 2d half hour }\end{array}$ & $\begin{array}{r}22 \\
6\end{array}$ & $\begin{array}{l}\text { Amber } \\
\text { Amber }\end{array}$ & $\begin{array}{l}8.6 \\
8.4\end{array}$ & $\begin{array}{l}12.8 \\
13.8\end{array}$ & $\begin{array}{l}16.9 \\
20.4\end{array}$ & $\begin{array}{l}1.8 \\
2.6\end{array}$ & $\begin{array}{l}0.9 \\
1.3\end{array}$ \\
\hline
\end{tabular}


TABLE V

Mean values with probable error of the mean of the trypsin, trypsin plus trypsinogen, lipase, and amylase of half hour samples in the various groups of patients with pernicious anemia and in normal subjects

I. Normals.

II. Pernicious anemia

1. Cases having moderate to advanced central nervous system involvement . . ...........

2. Cases having early or no demonstrable central nervous system involvement. .............

3. All cases having $\mathrm{RBC}$ below 3.0 million per c.mm.............

4. All cases having normal RBC...............

5. Cases having moderate to advanced central nervous system involvement and RBC below 3.0 million per c.mm...

6. Cases having moderate to advanced central nervous system involvement and a normal RBC

7. Cases having early central nervous system involvement and $R B C$ below 3.0 million per c.mm............

8. Cases having early or no demonstrable central nervous system involvement and normal RBC

9. Cases able to maintain RBC at normal levels on liver extract derived from $\mathbf{3 0 0}$ or less grams of liver. . . . . . . . . . .

10. Cases requiring more than the amount of liver extract derived from $\mathbf{3 0 0}$ grams of liver

11. All cases.

1

5

17

15

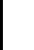

4

\section{4}

10

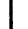

11.8

1

7

6

22
Mean values

\begin{tabular}{|c|c|}
\hline $\begin{array}{c}\text { Trypsin } \\
\text { and } \\
\text { trypsinogen }\end{array}$ & Lipase \\
\hline
\end{tabular}

$12.2 \pm 0.63$

$20.1 \pm 1.18$

$12.6 \pm 0.75$

$15.7 \pm 0.95$

$17.8 \pm 1.03$

$21.8+1.13$

$2.4 \pm 0.19$
$14.6 \pm 1.05$

$15.1 \pm 0.79$
$22.4 \pm 1.52$

$21.6 \pm 0.95$
27.21

$27.2 \pm 1.62$

N/10 $\stackrel{c c .}{\mathrm{N} a O H} \quad \begin{gathered}\text { mgm. } \\ \text { glucose }\end{gathered}$

$\begin{array}{ll}3.2 \pm 0.12 & 1.5 \pm 0.14\end{array}$

$1 \pm 0.23$

$1.6 \pm 0.18$

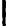

$2.4 \pm 0.17$

$2.2 \pm 0.18$

$1.1 \pm 0.17$

$2.0 \pm 0.16$

6

$1.4 \pm 0.16$

$1.0 \pm 0.21$

$20.2 \pm 1.31$

$27.8 \pm 1.21$

$2.4 \pm 0.18$

$2.3 \pm 0.19$

1.0

$1.7 \pm 0.22$

$2.3 \pm 0.29$

$.7 \pm 0.22$

1.0

$21.8 \pm 2.04$

$2.1 \pm 0.31$

$1.6 \pm 0.16$

$2.4 \pm 0.28$

$2.2 \pm 0.23$

$2.2 \pm 0.16$

$1.8 \pm 0.14$

\footnotetext{
* Probable error of mean.
} 


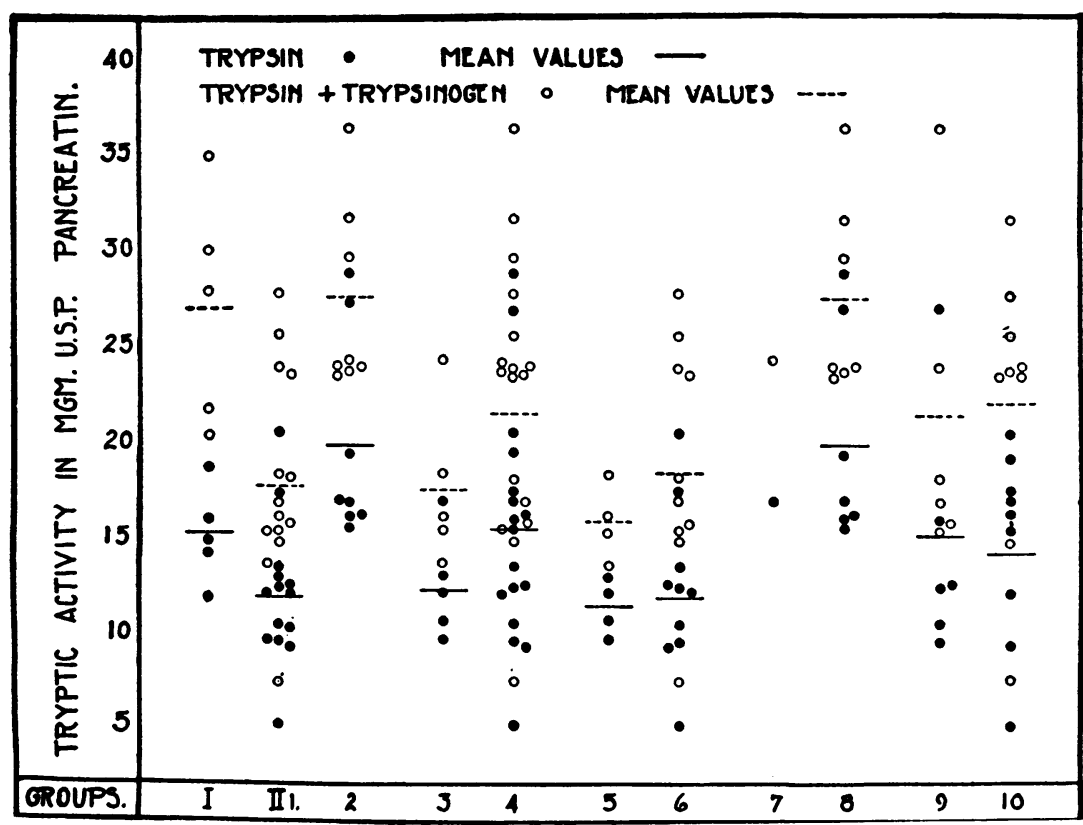

Chart 2. Individual VALUES OF TRYPSIN AND OF TRYPSIN AND TRYPSINOGEN Plotted According to Grouping in Table V

demonstrable central nervous system involvement. This finding was more evident when the tryptic activity of the samples after activation with enterokinase was studied. The amylolytic and lipolytic activity of the duodenal contents of the patients having moderate to advanced central nervous system involvement was also slightly decreased, but not to such a degree as the tryptic activity. One patient (Case number 2) with marked central nervous system involvement had the lowest trypsin values in the series, and, repeating the test three months later, similar results were obtained. Of the four patients having moderate to advanced central nervous system involvement, who had normal amounts of tryptic activity in the duodenal contents, three had recently shown definite improvement of symptoms referable to involvement of the central nervous system while receiving liver extract by injection.

There were only five patients having red blood counts below 3.0 million per c.mm., but in all there was a definite decrease in lipase and amylase and a slight decrease in trypsin. Fifteen of the patients had been studied by this department for a sufficient length of time to be used for determining the relationship of the duodenal contents with the maintenance dose of liver extract. The averages of the tryptic and lipolytic activity in those patients who were able to maintain the blood at normal levels by taking the amount of liver extract derived from 300 grams or 
less of whole liver daily, were approximately equal to those found in the patients requiring more liver extract. The average of the amylolytic activity of the latter group was slightly higher than that of the former. The one patient who was able to maintain the blood at normal levels while taking very small amounts of liver extract, however, had the highest tryptic activity in the duodenal contents of any of the fifteen patients.

\section{DISCUSSION}

In the 22 cases of pernicious anemia studied, there were no cases in which there was an absence of the pancreatic enzymes in the duodenal contents. This is in agreement with the findings of Crohn (7) (8), Chace and Myers (9), White (10), and McClure and associates (11), but is at variance with the findings of Cheney and Niemand (21). However, Cheney and Niemand based their opinion on the analyses of the fasting gastric contents. From our work it is evident that fasting gastric juice findings are not a satisfactory index of the external secretory function of the pancreas.

Although there were no cases in which there was a total absence of the pancreatic enzymes, it is interesting to note that, in all the patients with pernicious anemia having decreased amounts of tryptic enzymes, there was moderate to advanced central nervous system involvement present. We feel that this finding of low enzymatic activity in the duodenal contents of cases with achylia gastrica is of more significance than similar findings in cases having normal gastric function, because there was no free hydrochloric acid or pepsin to inhibit the pancreatic enzymes and, in addition, there was only a small amount of gastric juice in such cases to dilute the duodenal contents. The finding of decreased tryptic activity in the patients with pernicious anemia having moderate to advanced central nervous system involvement, suggests the possibility that a decrease in the external secretory function of the pancreas might be of etiological importance in the production of central nervous system involvement in pernicious anemia. A study of the duodenal contents of a larger series of cases is necessary to verify this possibility.

In this limited series, Case number 8 is the only one suggesting any correlation between maintenance dose of liver extract and the amount of pancreatic enzymes in the duodenal contents. This patient had one of the highest tryptic values in the whole series and was able to maintain the blood at normal levels for a period of $2 \frac{1}{2}$ years while taking the amount of liver extract derived from 100 grams of whole liver every other day. This suggests that the maintenance dose of liver extract in some patients with pernicious anemia may be influenced by the degree of activity of the pancreas; however, the findings in the remaining patients show no such relationship. The probability still remains that in the majority of the patients receiving an adequate diet and having no complications, the 
maintenance dose of liver extract is governed by the ability of the patient to absorb the active principle from the gastro-intestinal tract, as suggested by Castle and his associates (26).

\section{CONCLUSIONS}

1. Twenty-two cases of pernicious anemia were studied and all showed pancreatic enzymes in the duodenal contents.

2. The determination of pancreatic enzymes in the fasting gastric contents is of no value in estimating pancreatic activity.

3. The incubation of duodenal contents with enterokinase is necessary in order to determine the total amount of proteolytic enzymes secreted by the pancreas.

4. The ability of the duodenal mucosa to secrete enterokinase is apparently not impaired in pernicious anemia.

5. All patients with pernicious anemia who had decreased tryptic activity showed moderate to advanced central nervous system involvement.

6. With the possible exception of one case, there was no correlation between maintenance dose of liver extract and the activity of the pancreatic enzymes.

\section{BIBLIOGRAPHY}

1. Helmer, O. M., Fouts, P. J., and Zerfas, L. G., J. Clin. Invest., 1932, xi, 1129. Gastro-Intestinal Studies. I. Gastric Juice in Pernicious Anemia.

2. Castle, W. B., Am. J. M. Sc., 1929, clxxviii, 748. Observations on the Etiological Relationship of Achylia Gastrica to Pernicious Anemia. I. The Effect of the Administration to Patients with Pernicious Anemia of the Contents of the Normal Human Stomach Recovered after the Ingestion of Beef Muscle.

Castle, W. B., and Townsend, W. C., Am. J. M. Sc., 1929, clxxviii, 764. Observations on the Etiological Relationship of Achylia Gastrica to Pernicious Anemia. II. The Effect of the Administration to Patients with Pernicious Anemia of Beef Muscle after Incubation with Normal Human Gastric Juice.

3. Ehrmann, R., and Lederer, R., Berl. klin. Wchnschr., 1908, xlv, 1450. Ueber die Wirkung der Salzsäure auf die Fermentsekretion des Magens und der Bauchspeicheldrüse.

4. Einhorn, M., J. A. M. A., 1910, lv, 6. Experiences with the Duodenal Contents.

5. Einhorn, M., Am. J. M. Sc., 1914, cxlviii, 490. Direct Examination of the Duodenal Contents (also Bile) as an Aid in the Diagnosis of Gallbladder and Pancreatic Affections.

6. Einhorn, M., Am. J. M. Sc., 1918, clvi, 817. The Fractional Examination of the Duodenal Contents.

7. Crohn, B. B., Am. J. M. Sc., 1913, cxlv, 393. The Diagnosis of the Functional Activity of the Pancreatic Gland by Means of Ferment Analysis of the Duodenal Contents and of the Stools.

8. Crohn, B. B., Arch. Int. Med., 1915, xv, 581. Studies in Pancreatic Disease. 
9. Chace, A. F., and Myers, V. C., Arch. Int. Med., 1913, xii, 628. The Examination for Diagnostic Purposes of the Enzyme Activity of Duodenal Contents.

10. White, F. W., Boston Med. and Surg. J., 1916, clxxiv, 674. Observations on the Use of the Duodenal Tube for Diagnosis and Treatment.

11. McClure, C. W., and Jones, C. M., Boston Med. and Surg. J., 1922, clxxxvii, 909. Studies in Pancreatic Function. The Enzyme Concentration of Duodenal Contents in Pathological Conditions Involving the Pancreas, Liver, and Stomach.

12. Roth, N., and Sternberg, F., Deutsche med. Wchnschr., 1922, xlviii, 1207. Zur Frage der Pankreasachylie.

13. Kahn, H., Klin. Wchnschr., 1923, ii, 692. Zur Duodenalsondierung.

14. McClure, C. W., Montague, O. C., and Mortimer, E., Boston Med. and Surg. J., 1924, cxc, 357. Pancreatic Function in the Absence of Free Hydrochloric Acid from the Stomach.

15. Silverman, D. N., and Denis, W., South. M. J., 1924, xvii, 549. Studies of the Pancreatic Enzymes in Fasting Duodenal Contents.

16. Piersol, G. M., and Bockus, H. L., Arch. Int. Med., 1925, xxxv, 204. Pancreatic Enzymes in Cholecystitis.

17. Landau, A., Cygielstrejch, J., and Fejgin, M., Arch. d. mal. de l'app. digestif., 1926, xvi, 409. Achylie Gastro-Pancréatique.

18. Landau, A., and Glass, J., Arch. f. Verdauungskr., 1929, xlvi, 192. Achylia Gastro-pancreatica.

19. Martin, Lay, Arch. Int. Med., 1927, xxxix, 343. Biliary, Pancreatic, and Duodenal Studies. II. Estimation of Pancreatic Enzymes and Value of Such Determinations from a Clinical Standpoint.

20. Okada, S., Imazu, T., Kuramochi, K., Matsubara, M., Tsukahara, T., Arch. Int. Med., 1929, xliii, 413. Pancreatic Function. III. The Pancreatic Secretion in Disturbed Gastric Secretion.

21. Cheney, G., and Niemand, F., Arch. Int. Med., 1932, xlix, 925. A Possible Relationship of Pancreatic Insufficiency to Addison-Biermer (Pernicious) Anemia.

22. Richards, C. V., Arch. Int. Med., 1929, xliv, 71. An Improved Duodenal Tube. Its Advantages with a Brief Outline of Duodenal Intubation.

23. Wadsworth, J. V., and Aaron, A. H., Am. J. Surg., 1929, vii, 480. Observations on the Enzymatic Activities of the Duodenal Contents.

24. McClure, C. W., Wetmore, A. S., and Reynolds, L., Arch. Int. Med., 1921, xxvii, 706. New Methods for Estimating Enzymatic Activities of Duodenal Contents of Normal Man.

25. Helmer, O. M., Doctor's Thesis, University of Chicago, Sept. 1927. A Study of Trypsin and its Activation by Enterokinase.

26. Castle, W. B., Heath, C. W., and Strauss, M. B., Am. J. M. Sc., 1931, clxxxii, 741. Observations on the Etiologic Relationship of Achylia Gastrica to Pernicious Anemia. IV. A Biologic Assay of the Gastric Secretion of Patients with Pernicious Anemia Having Free Hydrochloric Acid and That of Patients without Anemia or with Hypochromic Anemia Having no Free Hydrochloric Acid, and the Role of Intestinal Impermeability to Hematopoietic Substances in Pernicious Anemia.

Castle, W. B., and Taylor, F. H. L., J. A. M. A., 1931, xcvi, 1198. Intravenous Use of Extract of Liver. 